\title{
Ayurveda and Allopathic Therapeutic Strategies in Coronavirus Pandemic Treatment 2020
}

\author{
Shivangi Talwar ${ }^{1} \cdot$ Shivani Sood $^{2} \cdot$ Jayant Kumar $^{2} \cdot$ Ritu Chauhan $^{1} \cdot$ Mamta Sharma $^{3} \cdot$ Hardeep Singh Tuli $^{4}$ (I)
}

Accepted: 6 October 2020 / Published online: 22 October 2020

(C) Springer Nature Switzerland AG 2020

\begin{abstract}
Purpose of Review In the last month of 2019, i.e., December, COVID-19 hit Wuhan city in China. Since then, it has infected more than 210 countries and nearly about 33.4 million people with one million deaths globally. It is a viral disease with flu-like symptoms; hence, prevention and management is the best option to be adopted for its cure.

Recent Findings Many healthcare systems, scientists, and researchers are fighting for the cure of this pandemic. Ayurvedic and allopathic treatments have been studied extensively and approached for the cure of COVID-19. In addition to ayurvedic treatments, the Ministry of Ayush, India, has also recommended many remedies to boost up immunity. Allopathic studies involved several antiviral drugs which were used in different combinations for the treatment of COVID-19.

Summary Comparative analysis of Ayurveda and allopathic treatment strategies were carried out in the present study. Depending upon the patient's conditions and symptoms, Ayurveda is useful for the treatment of COVID-19. Allopathic treatments inhibit viral infection by targeting majorly endocytosis, and angiotensin-converting enzyme (Ace) receptor signaling. In this article, we summarize different ayurvedic and allopathic medicines and treatment strategies which have been used for the treatment of COVID-19, a global pandemic.
\end{abstract}

Keywords COVID-19 $\cdot$ Symptoms $\cdot$ Ayurveda $\cdot$ Allopathic $\cdot$ Homeopathy

\section{Introduction}

In the last decade, different strains of coronaviruses had presented with challenging health issues to human society. The most popular viruses in this category are severe acute respiratory syndrome coronavirus (SARS-CoV) and Middle East respiratory syndrome coronavirus (MERS-CoV). With an increase in the population, migration, and social life, these viruses showed an increased rate in the recombination of intra- and inter-species

This article is part of the Topical Collection on Clinical Pharmacology

Hardeep Singh Tuli

hardeep.biotech@gmail.com

1 Amity Institute of Biotechnology, Amity University, Noida, Noida, India

2 Department of Biotechnology, Mukand Lal National College, Yamuna Nagar, India

3 School of Law, Justice and Governance, Gautam Buddha University, Greater Noida, India

4 Department of Biotechnology, Maharishi Markandeshwar (Deemed to be University), Mullana, Ambala 133207, India which made them adapt to every recent host [1]. In 2003, SARS-CoV was one of the most dangerous emergencies in the world for human infection. In its initial stage of infection, it infected nearly 1755 humans with 298 major cases. The severe acute respiratory syndrome coronavirus (SARS-CoV-2019) emerged in 2019 in the month of December in Wuhan city of China, which again made the life of humans miserable with numerous fatal health issues and slowly and gradually this virus entrapped the whole world $[2,3]$. The crown-shaped coronavirus leads to serious infections which was a brief part of the human SARS virus and affected the whole world which leads to a loss in business, tourism, and human life [1].

By the end of February 2020 and the start of March 2020, SARS-CoV-19 was declared as an international pandemic by the World Health Organization (WHO). The symptoms of this infection were similar to that of normal flu but included different categories like patients with mild symptoms, asymptomatic patients with no symptoms, and high symptomatic patients. Before the doctors, scientists, and researchers could study and come up with a cure for treatment, this virus had already infected more than lakhs of people across the world with the human coronavirus pathogens, i.e., $\mathrm{HCoV}-22 \mathrm{E}$ and $\mathrm{HCoV}-\mathrm{OC} 43$, 
which affects the upper respiratory tract. In 2005, the other novel pathogen of humans which were diagnosed during the SARS-CoV pandemic in the Netherlands included CoV-NL63 and HCoV-HKU1. This CoV-NL63 (group I) infected children suffering from bronchiolitis and the HCoV-HKU1 (group II) virus infected the adults in Hong Kong with chronic pulmonary infection. In September 2012, the WHO diagnosed another coronavirus which was MERS-CoV, which speeded up in a deadly manner in the Middle East, South Asia, and Africa and more than $75 \%$ of cases were diagnosed in Saudi Arab. It was identified that the family line of this virus is group 2 betacoronavirus, i.e., Tylonycteris bat coronavirus HKU4 (Bat-CoV HKU4) whose primary host is bats and HKU5CoVs pathogen whose primary host is Pipistrellus bats which are single-stranded positive RNA bat viruses which are widely distributed during the coronavirus pandemic and very close to humans for infection [4-7]. Bats were the primary host and act as a repository for causing infections not only in SARS-CoV, but were also a causative agent in the MERS $\mathrm{CoV}$. Additionally, camels were also suspected as a source of infection within the crossed species hindrance to contaminate people [8]. So it was remarked as bats are the significant supplies of various alpha coronaviruses and its ancestry of different beta coronaviruses [9]. In China, the common repository of the SARS viruses was the horseshoe bats, but bats being the definitive cause of the MERS virus species were yet to be discovered [10].

\section{Pandemic Virus COVID-19}

SARS-CoV virus is a ribonucleic acid-containing infectious agent, which is transferable from vertebrates to animals. SARS$\mathrm{CoV}$ infection is mainly developed in people through social contact and migration [11]. The viral genome has a basic protein named replicase which helps in the replication of the genetic genome in the host cell and is methylated at the $5^{\prime}$ end and the polyadenylated tail at $3^{\prime}$ end because of which the genetic material gets connected to the ribosome's and then replication starts [12]. On the other hand, there is a non-basic protein known as protease, used for the isolation of the proteins present in the chain $[13,14]$ which helps in the formation of different types of cytokines that leads to the production of lymphocytes. These lymphocytes act as a barrier and prevent viral genome from replicating which results in an increase in the inflammatory reactions [15]. This coronavirus is an enormous group with severe infections causing the symptoms like regular cold, fever, and respiratory disorders (shortness of breath), which helps the virus to propagate and leads to the replication and transmission. The basic symptom is common cold, which led to the discovery of six wellknown different species of coronaviruses which were first distinguished from the patients in the 1960s [16-19]. The incubation period of this virus is around about 5.8 days including the range of almost 2.1 to 11.1 days [20]. It is recommended by doctors and health organizations that coronavirus lasts for about 14 days which is the maximum time period and special precautions should be taken like social distancing, sanitization, self-quarantine, and wearing of masks and gloves [21]. The main target site for this crucial pathogenesis of the SARS-CoV includes the respiratory system and the main diseases which are related to heart injuries and anemia. The data records received from different hospitals across the world observed that by the end of 2019 and at the start of June 2020, it was reported that the COVID19 crisis leads to patients with the higher plasma level of proinflammatory cytokines like interleukin 1(IL-2), IL-6, IL-7, IL10, IL-12, interferons gamma (IFN $\gamma$ ), interferons alpha (IFN $\alpha$ ), tumor necrosis factor alpha (TNF $\alpha)$, and transforming growth factor beta (TGF $\beta)$ [22]. There are a large number of treatments and therapies available for this antiviral infection. But until now, there is no suitable vaccination for this pandemic but various pharmaceutical companies and researchers are working on it and human trials are going on. This short review summarizes the role of allopathic and Ayurveda in coronavirus infections. Each field plays an important role in their respective areas and will definitely prove fruitful in the early management of COVID19 patients. Until now, there is no treatment for coronavirus but our government has issued management and precaution guidelines along with a supporting healthcare system which could provide great relief in the outbreak of COVID-19. Many approaches like social distancing, wearing a mask, and medical grounds are used to control the pandemic disease. The main approach to regulate this disease was allopathic and Ayurveda.

\section{Role of Homeopathy and Ayurveda in COVID-19}

From the last 200 years in the late 1700s, a German physician named Dr. Samuel Hahnemann founded the homeopathy as a therapeutic medicine which helped to treat many epidemics, fearful, and severe diseases like cholera, fever, chikungunya, hepatitis, and malaria. The preventive measures of homeopathy are eminent and undeniable; as homeopathic medicines act remarkably on a health condition and cure the diseases. The scientific literature related to homeopathy is highly witnessed [23-26]. There are numerous confirmations that in the year 1918-1919, when Spanish flu emerged, homeopathy had shown amazing results, during which around about 21 million patients died around the world and about 5,00,000 in the USA alone. A study revealed that there was a difference in the mortality rate among the patients which were treated by homeopathy and physicians, i.e., 1-2\% appeared differently as they were treated by homeopathy as compare to $50-60 \%$ of patients who were treated by allopathic $[27,28]$. In homeopathic treatment, every patient after being fully diagnosed and analyzed received medicines. The medical grounds of 
homeopathy have a clear protocol of sanitation, antibiotics, and vaccinations to control the infections [29-31].

In diseases like dengue which causes hemorrhagic fever, homeopathy has helped in improving the platelet count and therefore there is a slowdown in the clinical center for about 2-3 days [32]. Likewise, there are many diseases in which homeopathy has acted as a buffer or control to decrease the mortality rate by about $15-16 \%$ conversely with the people who got simply institutional management. So, by looking at the past history, it can be observed that there are many instances in which homeopathy had shown extraordinary results and it can be equivalently used for the COVID patients but no study has shown its effects on Covid-19. The homeopathic medicines like Belladonna 3c, Eupatorium perfoliatum Q, Grindelia, Calcarea carb, Chinimum sulph, Bryonia, Gelsemium, Phosphorus, Thymulin, Camphora, Influenzinum, Antim tart, and a combination of few tinctures and homeopathic drugs prove to have a high rate of frequency to reduce severe pain, ache, and many more ailments in viral diseases [33].

There were numerous people who were infected by the virus and showed progressive circulation in their history in China's Wuhan village in December 2019 [34]. The name of the homeopathic therapies was previously reported to prevent viral infections that are presented henceforth [35-38]. Arsenicum album is formed when for continuously 2-3 days arsenic is heated with distilled water. On the basis of the fact sheet released by the CCRH (Central Council for Research in Homeopathy), Arsenicum album 30 can be considered as "prophylactic medicine" COVID-19 [39]. The inflammatory symptoms shown by COVID-19, Arsenic toxicity, and HIV infection are the same and there is a definite synergy between them and may have the suitable potential to aggravate each other. Therefore, Arsenicum album may be considered as a suitable remedy for COVID-19 treatment. Arsenic is one of the constituents in it which showed its enumerating impact on the different macrophage cells as well on tumor cells. Also, it showed decreased NF- $\kappa \beta$ hyperactivity (nuclear factor kappalight-chain-enhancer of activated B cells; diminished verbalization of reporter quality of green fluorescent protein (GFP) in transfect HT29 cells) and decreased TNF- $\alpha$ (tumor necrosis factor-alpha) release in macrophages. Arsenic album-30 was advised to be taken once in a day for 3 days. The tincture of album-20 is arsenic trioxide which is highly diluted and it works to prevent disease [37]. The proposed mechanism of action of Arsenicum is shown in Fig. 1. Until now, there is no

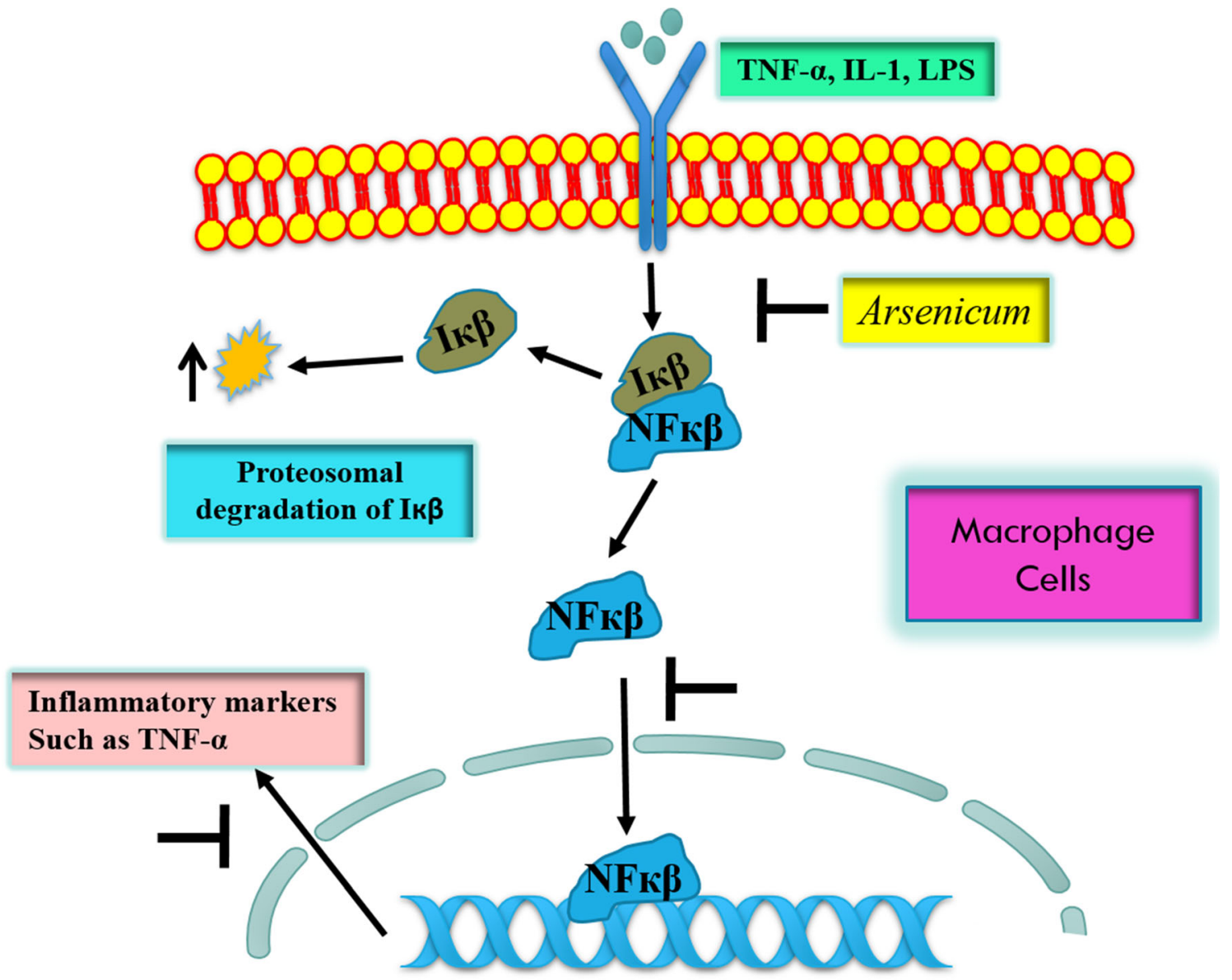

Fig. 1 Schematic representation of mechanistic insight of Arsenicum via downregulation of NF-к $\beta$ and TNF- $\alpha$ in macrophages 
clinical proof for homeopathy medicine as a drug for COVID19 treatment $[40,41]$.

Furthermore, for more than 3000 years, Ayurveda, a Sanskrit word, originated in India. Nowadays, it is considered as a traditional system of medicine which helps in the management of infection and maintains the homeostasis of disease. It also helps in building the strength of the mind and soul, and teaches the body to fight against stress. During COVID-19, Ayurveda is also playing an important role as it has enough possibilities and potential for the prevention of infection and treatment for corona victims. The asymptomatic cases in India help in implementing the role of Ayurveda, through the regular use of Ayurveda medicines and home remedies. But still, the confirmation imagined by Traditional Chinese Medicine (TCM) cannot be disregarded in China [42, 43]. This is directly understood that at the time of the pandemic, approximately 3100 TCM-related workers had been passed on to the Hubei district. TCM was officially accepted by the Chinese guideline on end and used as a cure for COVID-19 $[44,45]$. This is especially important to observe that specific TCM wards were set up, and quarantine centers were developed which had used Chinese drugs for treatment using western medication [42].

With the accomplishment of TCM in controlling an infectious pandemic, it was reasonable and major to examine how
Ayurveda can help in treating COVID-19 [46, 47]. By this time, it was the Ministry of AYUSH which created a standard to change Indian social protection [48] and to show the power of AYUSH to build up prosperity [49]. With this ultimate objective of AYUSH, Ayurveda during the COVID-19 pandemic, people were divided into four specific classifications [50] along with characters and natural herbs for treatment which is tabulated in Table 1.

This classification has huge necessary information which was complete and well managed. Subsequently, it is advised that genuine information of factors that are important should be done on each case. These variables should incorporate age, sex, manifestations, topography, and contact history which results in a clear prescription and should be recorded. On the other hand, TCM did not control COVID-19 cases. Equivalent philosophy was also adopted and has been used in Ayurveda and it should pursue its own skill for finding and coming about remedies optional on roga and rogi bala.

\section{Role of Allopathic in COVID-19}

In the allopathic approach, treatment in coronavirus included intravenous infusion of fluid, oxygen therapy, and life support

Table 1 Four specific classifications of Ayurveda medication during the pandemic period of COVID-19

\begin{tabular}{|c|c|c|c|}
\hline Groups & Characters & Herbs & Reference \\
\hline $\begin{array}{l}\text { No symptoms and also } \\
\text { unexposed }\end{array}$ & $\begin{array}{l}\text { Do not assimilate those people who do } \\
\text { not have related side effects neither } \\
\text { they have hazard issues. They doubtless } \\
\text { they are most likely invulnerable } \\
\text { from disease because of } \\
\text { parthenogenesis [48] }\end{array}$ & $\begin{array}{l}\text { For purification of the body herbs like Allium } \\
\text { sativum strip, Curcuma longa powder, } \\
\text { Trachyspermum ammi seeds, } \\
\text { and Loban were used whereas for respiratory tract } \\
\text { Swarna Prashana, and mass prophylaxis } \\
\text { of rasayana, Brahma Rasayana, Chyavanprasha } \\
\text { or Amrit Bhallataka, Rasayana + Samhita were } \\
\text { used }\end{array}$ & {$[51-60]$} \\
\hline Mild symptoms & $\begin{array}{l}\text { Have very less symptoms like fever, } \\
\text { tiredness, cough, etc. and no need } \\
\text { to be hospitalized. Home quarantine } \\
\text { and to maintain social distance } \\
\text { with family members too. }\end{array}$ & $\begin{array}{l}\text { Nardiya, Ginger Root, Gojihvaadi Kashaya, } \\
\text { Pippali rasayana, Sanjeevani vati, C. vati, } \\
\text { Solanum surattense, Dashamul kwath, } \\
\text { Talishadi Sitopaladi, and Yashtimadhu }\end{array}$ & {$[61],[68-70]$} \\
\hline Medium symptoms & $\begin{array}{l}\text { Moderate to maximum symptoms. } \\
\text { Took place with high hazard gathering. } \\
\text { Severe symptoms like difficulty } \\
\text { in breathing, pain in chest, and } \\
\text { deafness; also, they can lose } \\
\text { movement too. The patient took } \\
\text { into consideration from initial stage } \\
\text { and co-recommended with Ayurveda } \\
\text { drugs. }\end{array}$ & $\begin{array}{l}\text { P. rasayana, Laghu Vasant Glycyrrhiza glabra, } \\
\text { Semecarpus anacardium, Tribhuvan keerti } \\
\text { rasa Brihata Vata Chintamni rasa, Mrityunjaya } \\
\text { rasa, and Siddha makardhvaja rasa }\end{array}$ & [69], [71-74] \\
\hline Quarantined & $\begin{array}{l}\text { People who did not have any clear signs } \\
\text { but still they are in danger because of } \\
\text { contact history with patients. } \\
\text { Tested on the basis of their contact } \\
\text { history. }\end{array}$ & $\begin{array}{l}\text { Sanjeevani vati, Chitrakadi vati, Guduchi } \\
\text { (Tinospora cordifolia), Shunthi (Zingiber } \\
\text { officinale), } \\
\text { Haridra (C. longa), Sanjivani vati, T. cordifolia, } \\
\text { Z. officinale, C. longa, Ocimum sanctum, } \\
\text { Glycyrrhiza glabra, Adhatoda vasica, } \\
\text { Andrographis paniculata, Swertia chirata, } \\
\text { Moringa oleifera, Triphala }\end{array}$ & {$[61-67]$} \\
\hline
\end{tabular}


system in critical cases. It was advisable if anyone prevails symptoms of the virus like flu, fever, and breathlessness, they should contact the doctor immediately. This virus is similar to the human immunodeficiency virus (HIV) in terms of virus replication and proteins. Different administrating drugs were found to clear and handle in vitro action against SARS-CoV and MERS-CoV [75, 76].

\section{Chloroquine and Hydroxychloroquine}

Chloroquine and hydroxychloroquine have a possibility of curing an intestinal disorder, systemic lupus erythematosus (SLE), and rheumatoid joint torment (RA) [77]. Chloroquine and hydroxychloroquine obstruct glycosylation of host receptors, proteolytic, and maturation of endosomes. These mechanisms have immunomodulatory shocks to host cells by bringing down the cytokine level and control of autophagy and lysosomal $[78,79 \bullet \cdot]$. In vitro studies revealed that in the low micromolar concentration, chloroquine crushes SARS-CoV-2 with a halfmaximal credible center (EC50) and hydroxychloroquine with a lower EC50 for SARS-CoV-2 differentiated, i.e., $\mathrm{EC} 50=6.14 \mu \mathrm{M}$ and chloroquine: $\mathrm{EC} 50=23.90 \mu \mathrm{M}$ $[80 \bullet \cdot$.

The treatment of COVID-19 included the oral dosage of chloroquine $(500 \mathrm{mg}$ ) and hydroxychloroquine $(400 \mathrm{mg})$ on daily basis [81-83]. But still, there is a lack of data which proves the mechanism of chloroquine and hydroxychloroquine. Pharmacokinetic studies reviewed that the ideal dose of hydroxychloroquine for treating COVID-19 patients should be replaced by $200 \mathrm{mg}$ twice instead of $400 \mathrm{mg}$ on daily basis [80••]. Unusually, elective outlines are made for $600 \mathrm{mg}$ of total dose step by step by dividing reliant on freedom and clinical experience for Whipple's disease [81].

\section{Lopinavir/Ritonavir and Other Antiretrovirals}

The Food and Drug Administration (FDA), USA, recommended and certified lopinavir/ritonavir, an oral drug for HIV, with in vitro activity against other novel coronaviruses through the control of 3-chymotrypsin-like protease [84, 85]. There is no in vitro study data for lopinavir/ritonavir against SARS-CoV-2 [86] but a review on lopinavir/ritonavir was assessed for the treatment of SARS and MERS which showed clinical observations and analysis of SARS with less mortality rate and incubation rates, along with experimental research. The studies revealed that drugs should be used during the early stages of viral replication, i.e., beginning 7-10 days; otherwise, late initiation with lopinavir/ritonavir had no effect on clinical outcomes [87, 88].

\section{Ribavirin}

A guanine basic drug named ribavirin handles viral ribonucleic-subordinate and polymerase whose activity against various coronavirus makes it a challenger for the treatment of the COVID-19 outbreak. In vitro studies of this drug proved to show advancement against SARS$\mathrm{CoV}$ by blocking the replication of the virus. This mechanism required a high dose of this drug, i.e., 1.2 to $2.4 \mathrm{~g}$ orally as expected along with blend treatment. Past studies told that the patients got either endogenous or enteral cooperation [89] and no data exists in its role with the respiratory syncytial disease in COVID-19 [90]. The trial on 30 patients confessed questionable results in which out of 30 examinations, 26 were re-evaluated, with 4 assessments exhibiting hematologic and liver toxicity [38]. On the other hand, in the treatment of MERS, ribavirin was mixed with interferons and its clinical studies resulted in no observable and remarkable effect on viral clearance [77, 91]. Due to a lack of clinical data with ribavirin for SARS-CoV-2 strategies, its supportive occupation must be extrapolated from other $\mathrm{nCoV}$ data.

\section{Remdesivir}

Remdesivir (other name GS-5734) is a prodrug monophosphate which helps in the absorption of $\mathrm{C}$ adenosine nucleoside triphosphate. It was studied that the antimicrobial activity of this drug against RNA proved to be contagions especially in the family of Coronaviridae and Flaviviridae. Due to its low EC50 value, it proved to be therapeutic against the emergence of Ebola virus disease based on its selectivity against host polymerase of Ebola [92•]. Because of broad reach, presently, remdesivir and its in vitro studies against coronavirus help in treating SARS-CoV-2 with EC50 and EC90 estimations of $0.77 \mu \mathrm{M}$ and $1.76 \mu \mathrm{M}$, respectively, and are proved to be a fruitful expected treatment for COVID$19[93 \bullet \bullet, 94 \bullet \bullet]$. On the other hand, in murine lung defilement models accompanied by MERS-CoV, remdesivir drug prohibited the lung channel and lessened viral lung titers more than comparator agents [94*0].

\section{Dexamethasone}

Dexamethasone is a type of chemically derived corticosteroid which acts as an immunosuppressor. It abridged deaths by $1 / 3$ in patients getting invasive mechanical ventilation and by $1 / 5$ in patients being delivered oxygen without invasive mechanical ventilation. However, therapy did not decrease the death in patients not getting breathing support at randomization. Therefore, 


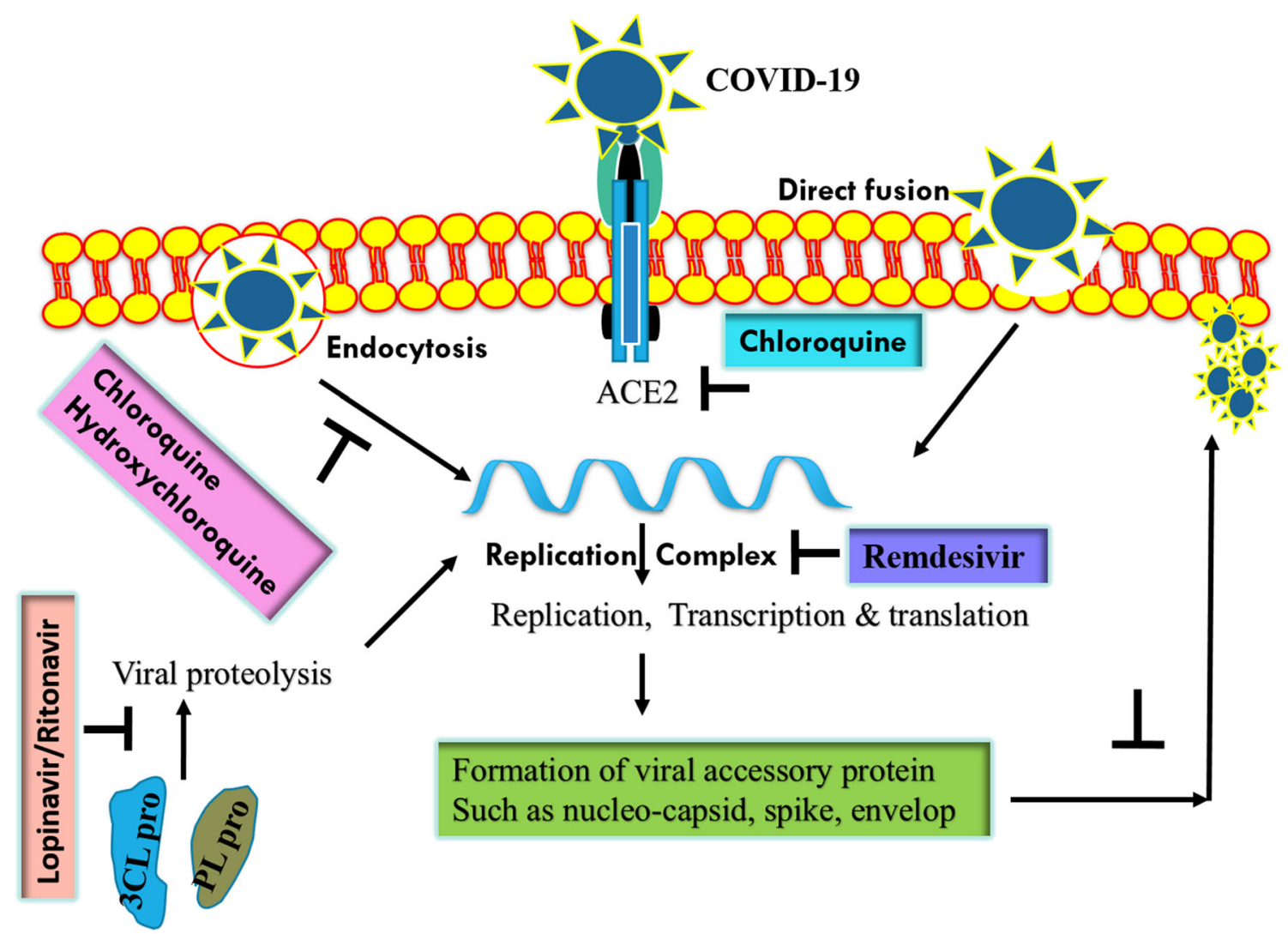

Fig. 2 This illustration depicts the mechanisms of action of allopathic drugs via various routes including inhibition of endocytosis process, viral proteolysis, replication complex, and ACE2 during COVID-19 infection

dexamethasone abridged 28-day mortality among those getting invasive mechanical ventilation [95・•]. Mechanistically, it inhibits the growth of the cytokines which cause infection and is therefore useful in this COVID-19-related hyperinflammation or cytokine storm. It has a high rate of activity and also lasts for a longer duration as compared to other cortisone [96-101]. Studies have shown that it is only useful in those cases where the condition of the patient is critical and cannot be used for the generalized treatment of all patients [102]. The mode of action of various allopathic drugs is summarized in Fig. 2. These above-discussed drugs mainly inhibit angiotensin-converting enzyme 2 (ACE2), endocytosis, non-structural protein $3 \mathrm{C}$-like protease, and nonstructural proteins RNA-dependent RNA polymerase (RdRp) to stop viral infection and growth.

\section{Conclusion}

COVID-19 is considered as pandemic worldwide and spreading at an alarming rate. Therefore, it has been essential to explore various strategies to overcome the effect of this dreadful viral disease. This review summarizes the utility of currently opted therapies for COVID-19. No suitable medicine is found to exist currently for this virus infection. The rapidly increasing patient's data of COVID-19 is triggering scientific communities to come forward to develop some possible therapy. The most reassuring treatment is considered to be remdesivir. This drug is known to possess strong antiviral activity as proven by several in vitro studies. Oseltamivir has not presented with suitability, and corticosteroids are at present not recommended. On the other hand, homeopathy and Ayurveda may be promising, but not applicable towards all types of patients. Therefore, the present study concludes that COVID-19 infection can be prevented by following government guidelines and opting immune-boosting Ayurveda routes.

Acknowledgments The authors want to thank Maharishi Markandeshwar (Deemed to be University) for providing the requisite facility. We acknowledge Dr. Vaishali Aggarwal, Department of Pharmaceutical Sciences, University of Pittsburgh, USA, for her guidance.

\section{Compliance with Ethical Standards}

Conflict of Interest None

Human and Animal Rights and Informed Consent This article does not contain any studies with human or animal subjects performed by any of the authors. 


\section{References}

Papers of particular interest, published recently, have been highlighted as:

- Of importance

- Of major importance

1. Lau SKP, Chan JFW. Coronaviruses: emerging and re-emerging pathogens in humans and animals. Virol J. 2015;12:1-13. https:// doi.org/10.1186/s12985-015-0432-z.

2. Lau SKP, Woo PCY, Li KSM, Huang Y, Tsoi H-W, et al. Severe acute respiratory syndrome coronavirus-like virus in Chinese horseshoe bats. PNAS. 2005;102:14040-5. https://doi.org/10. 1073/pnas.0506735102.

3. Ge X-Y, Li J-L, Yang X-L, Chmura AA, Zhu G, Epstein JH, et al. Isolation and Characterization of a bat SARS-like coronavirus that uses the ACE2 receptor. Nature. 2013;503:535-8. https://doi.org/ 10.1038/nature12711.

4. Zaki AM, Van Boheemen S, Bestebroer TM, Osterhaus AD, Fouchier RA. Isolation of a novel coronavirus from a man with pneumonia in Saudi Arabia. N Engl J Med. 2012;367:1814-20. https://doi.org/10.1056/NEJMoa1211721.

5. Woo PCY, Wang M, Lau SKP, Xu H, Poon RWS, et al. Comparative analysis of twelve genomes of three novel group $2 \mathrm{c}$ and group $2 \mathrm{~d}$ coronaviruses reveals unique group and subgroup features. J Virol. 2007;81:1574-85. https://doi.org/10.1128/JVI. 02182-06.

6. Lau SK, Li KS, Tsang AK, Lam CS, Ahmed S, Chen H, et al. Genetic characterization of Betacoronavirus lineage $\mathrm{C}$ viruses in bats reveals marked sequence divergence in the spike protein of Pipistrellus bat coronavirus HKU5 in Japanese pipistrelle: implications for the origin of the novel Middle East respiratory syndrome coronavirus. J Virol. 2013;87:8638-50. https://doi.org/10. 1128/JVI.01055-13.

7. Haagmans BL, Al Dhahiry SH, Reusken CB, Raj VS, Galiano M, Myers R, et al. Middle East respiratory syndrome coronavirus in dromedary camels: an outbreak investigation. Lancet Infect Dis. 2014;14:140-5. https://doi.org/10.1016/S1473-3099(13)70690-X.

8. Chan JFW, Lau SKP, kelvin KW to, Cheng VCC, Woo PCY, Yuen K-Y. Middle East respiratory syndrome coronavirus: another zoonotic Betacoronavirus causing SARS-like Disease. Clin Microbiol. 2015;28:465-522. https://doi.org/10.1128/CMR. 00102-14.

9. Woo PCY, Lau SKP, Lam CSF, Lau CCY, Tsang AKL, et al. Discovery of seven novel mammalian and avian coronaviruses in Deltacoronavirus supports bat coronaviruses as the gene source of Alphacoronavirus and Betacoronavirus and avian coronaviruses as the gene source of Gammacoronavirus and Deltacoronavirus. J Virol. 2012;86:3995-4008. https://doi.org/10.1128/JVI.06540-11.

10. Hu B, Ge X, Wang L-F, Shi Z. Bat origin of human coronaviruses. Virl J. 2015;12:1-10. https://doi.org/10.1186/s12985-015-0422-1.

11. Cui J, Li F, Shi Z-L. Origin and evolution of pathogenic coronaviruses. Nat Rev Microbiol. 2019;17:181-92. https://doi. org/10.1038/s41579-018-0118-9.

12. Sexton NR, Smith EC, Blanc H, Vignuzzi M, Peersen OB, Denison MR. Homology-based identification of a mutation in the coronavirus RNA-dependent RNA polymerase that confers resistance to multiple mutagens. J Virol. 2016;90(16):7415-28. https://doi.org/10.1128/JVI.00080-16.PMID27279608.

13. Fehr AR, Perlman S. Coronaviruses: an overview of their replication and pathogenesis. Methods Mol Biol. 2015;1282:1-23. https://doi.org/10.1007/978-1-4939-2438-7_1.

14. World Health Organization. Statement on the second meeting of the International Health Regulations (2005) Emergency
Committee regarding the outbreak of novel coronavirus (2019nCoV). 2020. https://www.who.int/news/item/30-01-2020statement-on-the-second-meeting-of-the-international-healthregulations-(2005)-emergency-committee-regarding-theoutbreak-of-novel-coronavirus-(2019-ncov).

15. Opal SM, Girard TD, Ely EW. The immunopathogenesis of sepsis in elderly patients. Clin Infect Dis. 2005;41:S504-12. https://doi. org/10.1086/432007.

16. Adam Felman. What's to know about coronaviruses? Medical news today. 2020 Available from: https://www. medicalnewstoday.com/articles/256521.php. Accessed 29 January 2020.

17. Huang C, Wang Y, Li X, Ren L, Zhao J, Hu Y, et al. Clinical features of patients infected with 2019 novel coronavirus in Wuhan, China. Lancet. 2020;395:497-506. https://doi.org/10. 1016/S0140-6736(20)30183-5.

18. Chen N, Zhou M, Dong X, Jieming Q, Gong F, Yang H, et al. Epidemiological and clinical characteristics of 99 cases of 2019 novel coronavirus pneumonia in Wuhan, China a descriptive study. Lancet. 2020;395:507-13. https://doi.org/10.1016/S01406736(20)30211-7.

19. Wang D, Hu B, Hu C, et al. Clinical characteristics of 138 hospitalized patients with 2019 novel coronavirus-infected pneumonia in Wuhan, China. JAMA. 2020;323:1061-9. https://doi.org/10. 1001/jama.2020.1585 (Study highlights the COVID-19 patient's characterization features).

20. Backer JA, Klinkenberg D, Wallinga J. Incubation period of 2019 novel coronavirus (2019-nCoV) infections among travellers from Wuhan, China, 20-28 January 2020. Euro Surveill. 2020;25. https://doi.org/10.2807/1560-7917.ES.2020.25.5.2000062.

21. Lauer SA, Grantz KH, Bi Q, Jones FK, et al. The incubation period of coronavirus disease 2019 (COVID-19) from publicly reported confirmed cases: estimation and application. Ann Intern Med. 2020. https://doi.org/10.7326/M20-0504.

22. World Health Organization. Clinical management of COVID-19. 2020. https://www.who.int/publications/i/item/clinicalmanagement-of-covid-19.

23. Bala R, Srivastava A. Historical Journey of Homoeopathy during Epidemic Diseases in the Light of 2019 Novel coronavirus pandemic. Int J Sci Healthc Res. 2020(5):215-33 ISSN: 2455-7587.

24. Jacobs J. Homeopathic prevention and management of epidemic diseases. Homeopathy. 2018;107:157-60. https://doi.org/10. 1055/s-0038-1649487.

25. Hahnemann S. Organon of Medicine. 6th ed. New Delhi: B Jain Publishers; 2004. p. 267.

26. Harilal KN, Thyagaraj AP, Thomas MV, Suresh AT. Development of homoeopathic genus Epidemicus for secondary level prevention of dengue virus infection at Kannur, Kerala. 2020. https://www.researchgate.net/publication/326742719. Accessed 22February 2020.

27. Winston J. The Faces of Homśopathy. Articles on homeopathy. Wellington, New Zealand: Great Auk Publishing; 1999. www. omeoint.org/winston/faces.html. Accessed 1 Aug 2001.

28. Dewey WA. Homeopathy in Influenza - a chorus of fifty in harmony. J Am Inst Homeo. 1920-21;13:1038-43.

29. Hasan N, Uddin Md M, Nayem R, Mohshinuzzaman M, Biswas $\mathrm{AH}$, Kayes E, et al. Homeopathic approach to COVID-19: a review. Malays J Med Biol Res. 2020;7:39-44. https://doi.org/10. 18034/mjmbr.v7i1.493.

30. Pal PP, Ningthoujam G. Research review of genus Epidemicus. Int J Adv Ayurveda, Yoga, Unani, Siddha and Homeopathy. 2019;8:545-50.

31. Milgrom LR. Genus Epidemicus: are notions of entanglement relevant to the homeopathic understanding of epidemic disease? Complementary medicine Research. 2016;23:290-300. 
32. Nayak D, Chadha V, Jain S, Nim P, Sachdeva J, Sachdeva G, et al. Effect of adjuvant homeopathy with usual care in management of thrombocytopenia due to dengue: a comparative cohort study. Homeopathy. 2019;108:150-7. https://doi.org/10.1055/s-00381676953.

33. Oberai P, Varanasi R, Padmanabhan M, Upadhyaya A, Singh S. Effectiveness of homeopathic medicines as add-on to institutional management protocol for acute encephalitis syndrome in children: an open-label randomized placebo controlled trial. Homeopathy. 2018;107:161-71. https://doi.org/10.1055/s-0038-1656715.

34. First COVID-19 case can be traced back to November 17 in China' 521 Hubei province: Report. The Economic Times. https://economictimes.indiatimes.com/news/international/worldnews/first-covid-19-case-can-be-traced-back-to-november-2017in-chinas-hubei-province-report/articleshow/74608199.cms? utm_source=contentofinterest\&amp;utm_medium=text\&amp; utm_campaign=cppst. Accessed 13 March 2020.

35. Government of India. Advisory for Corona virus. Press Information Bureau 2020. https://pib.gov.in/pressreleasepage. aspx?prid=1600895. Accessed 29 January 2020.

36. Mathie RT, Baitson ES, Frye J, Nayak C, Manchanda RK, Fisher P. Homeopathic treatment of patients with influenza-like illness during the 2009 A/H1N1 influenza pandemic in India. Homeopathy. 2013;102:187-92. https://doi.org/10.1016/j.homp. 2013.04.001 (Role of homeopathic strategies to fight against viral infections).

37. Chakraborty PS, Lamba CD, Nayak D, John MD, Sarkar DB, Poddar A, et al. Effect of individualized homoeopathic treatment in influenza like illness: a multicenter, single blind, randomized, placebo controlled study. Indian J Res Homoeopathy. 2013;7:2230. https://doi.org/10.4103/0974-7168.114268.

38. Gupta J, Rao MP, Kolli R, Prasad RVR, Arya JS, Mondal BK, et al. Management of early years of simple and mucopurulent chronic bronchitis with pre-defined homeopathic medicines - a prospective observational study with 2-years follow-up. Int $\mathbf{J}$ High Dilution Res. 2019; 18:47-62.

39. https://indianexpress.com/article/explained/debate-over-ahomoeo-drug-arsenicum-album-coronavirus-vaccine-6439697/

40. https://science.thewire.in/the-sciences/covid-19-homeopathyarsenicum-album-succusion-ministry-of-ayush/

41. Bellavite P, Signorini A, Marzotto M, Moratti E, Bonafini C, Olioso D. Cell sensitivity, non-linearity and inverse effects. Homeopathy. 2015;104:139-60. https://doi.org/10.1016/j.homp. 2015.02.002.

42. Ren JL, Zhang AH, Wang XJ. Traditional Chinese medicine for COVID-19 treatment. Pharmacol Res. 2020;155:104743. https:// doi.org/10.1016/j.phrs.2020.104743 (This study describes the utility of TCM therapeutic agents to combat COVID-19).

43. Cui HT, Li YT, Guo LY, Liu XG, Wang L-S, et al. Traditional Chinese medicine for treatment of coronavirus disease 2019: a review. 2020;5:65-73. https://doi.org/10.12032/ 560TMR20200222165.

44. National health commission of the people's republic of china. Guidelines on diagnosis and treatment of covid-19 2020. http://www.Nhc.Gov.Cn/ xcs/zhengcwj/202002/8334a8326dd94d329df351d7da8aefc2.Shtm.

45. Rastogi S, Pandey DN, Singh RH. COVID-19 pandemic: a pragmatic plan for ayurveda intervention. J Ayurveda Integr Med. 2020. https://doi.org/10.1016/j.jaim.2020.04.002.

46. Patwardhan B, Gautam PC, Gautam M, Tillu G, Chopra A, Gairola S, et al. Ayurveda rasayana in prophylaxis of covid-19. Curr Sci. 2020;118:1158-60.

47. Patwardhan B, Tillu G. Universal Health Coverage and AYUSH systems. J Ayurveda Integr Med. 2018;9:1-2. https://doi.org/10. 1016/j.jaim.2018.03.001.
48. Tillu G. AYUSH research for New India: Vision and strategies. J Ayurveda Integr Med. 2018;9:240-4. https://doi.org/10.1016/j. jaim.2018.06.001.

49. Brown P. Studying COVID-19 in light of critical approaches to risk and uncertainty: research pathways, conceptual tools, and some magic from mary douglas. Health Risk Soc. 2020;22:1-14. https://doi.org/10.1080/13698575.13692020.11745508.

50. Hotchkiss RS, Opal SM. Activating immunity to fight a foe - a new path. N Engl J Med. 2020;26:1270-2. https://doi.org/10. 1056/NEJMcibr1917242.

51. Bhatwalkar SB, Shukla P, Srivastava RK, Mondal R, Anupam R. Validation of environmental disinfection efficiency of traditional Ayurvedic fumigation practices. J Ayurveda Integr Med. 2019;10: 203-6. https://doi.org/10.1016/j.jaim.2019.05.002.

52. Patil A, Dindore P, Aziz A, Kadam A, Saroch V. Clinical effect of suvarna bindu prashan. J Ayurveda Integr Med Sci. 2017;2:11-8. https://doi.org/10.21760/jaims.v21762i21763.28203.

53. Rastogi S. Translational Ayurveda. Singapore: Springer; 2019. Ayurvedic rasayana therapy: a rational understanding necessary for mass benefits. p. 77-99. https://doi.org/10.1007/978-981-132062-0.

54. Sharma R, Martins N, Kuca K, Chaudhary A, Kabra A, Rao MM, et al. Chyawanprash: a traditional Indian bioactive health supplement. Biomolecules. 2019;9:161. https://doi.org/10.3390/ biom9050161.

55. Rege NN, Thatte UM, Dahanukar SA. Adaptogenic properties of six rasayana herbs used in Ayurvedic medicine. Phytother Res. 1999;13:275-91. https://doi.org/10.1002/(SICI)10991573(199906)13:4<275::AID-PTR510>3.0.CO;2-S.

56. Rastogi S. Building bridges between Ayurveda and Modern Science. Int J Ayurveda Res. 2010;1:41-6. https://doi.org/10. 4103/0974-7788.59943.

57. Rekha PS , Kuttan G, Kuttan R. Antioxidant activity of brahma rasayana. IIndian J Exp Biol. 2001; 39:447-452.

58. Shastri SN. Charaka samhit chikitshyasthan-30/238. Reprint. Varanasi: Chaukhambha bharati Academy; 2011.p. 872.

59. Srikantha Murthy K., editor. vol. I. Chaukhambha Orientalia; Varanasi: 2014. p. 502.

60. Rastogi S, Rastogi R, Singh RH. Adverse effects of Ayurvedic drugs: an overview of causes and possibilities in reference to a case of Vatsanabha (Aconite) overdosing. Int J Risk Saf Med. 2007;19:117-25.

61. Tripathi JS, Singh RH. Possible correlates of free radicals and freeradical mediated disorders in Ayurveda with special reference to Bhutagni Vyapara and Ama at molecular level. Anc Sci Life. 1999;19:17-20.

62. Murthy K.S. Sarangadhara-Samhita: a treatise on Ayurveda, Madhyam khanda,. Chaukhambha Orientalia; Varanasi: 2012. p. 103.

63. The Ayurvedic Formulary of India. Vati prakarana. New Delhi: Controller of Publications; 2000. p. 154.

64. Aparna A, Rege A, Chowdhary AS. Evaluation of Ocimum sanctum and Tinospora cordifolia as probable HIV-protease inhibitors. Int J Pharmaceut Sci Rev Res. 2014;25:315-8.

65. Rege AA, Chowdhary AS. Evaluation of some medicinal plants as putative HIV-protease inhibitors. Indian Drugs. 2013;50:24-8.

66. Panche AN, Chandra S, Diwan AD. Multi-target $\beta$-protease inhibitors from Andrographis paniculata: In Silico and In Vitro Studies. Plants (Basel). 2019;8:231. https://doi.org/10.3390/ plants8070231.

67. Srikanth NA, Singh SO, Sreedhar B, Dhimana GKS. Chemical characterization of an Ayurvedic herbo-mineral preparationMahalaxmivilas Rasa. J Ayurveda Integr Med. 2019;10:262-8. https://doi.org/10.1016/j.jaim.2018.01.002. 
68. Bisht D, Sharma YK, Mehra BL. A clinical study to evaluate the efficacy of Pippali Rasayana in certain respiratory disorders. Ayu. 2009;30:337-41.

69. Makhija IK, Shreedhara CS, Aswatha HN. Mast cell stabilization potential of sitopaladi churna: an Ayurvedic formulation. Pharm Res. 2013;5:306-8. https://doi.org/10.4103/0974-8490.118824.

70. Rastogi S, Srivastav PS. Ayurveda in critical care: illustrating Ayurvedic intervention in a case of hepatic encephalopathy. Ayu. 2011;32:345-8. https://doi.org/10.4103/0974-8520.93911.

71. Panigrahi HK. Efficacy of Ayurvedic medicine in the treatment of uncomplicated chronic sinusitis. Anc Sci Life. 2006;26(1-2):6-11.

72. Sharma R, Prajapati PK. Nanotechnology in medicine: leads from Ayurveda. J Pharm Bioallied Sci. 2016;8:80-1. https://doi.org/10. 4103/0975-7406.171730.

73. Bhole TP, Patil S, Wele AA. Assessment of bioavailability of gold bhasma in human participants - a pilot study. J Ayurveda Integr Med. 2018;9:294-7. https://doi.org/10.1016/j.jaim.2018.04.002.

74. Stockman LJ, Richard Bellamy R, Garner P. SARS: Systematic review of treatment effects. PLoS Med. 2006;3:e343. https://doi. org/10.1371/journal.pmed.0030343.

75. Morra ME, Thanh LV, Kamel MG, Ghazy AA, Altibi AMA, Dat LM, et al. Clinical outcomes of current medical approaches for Middle East respiratory syndrome: a systematic review and metaanalysis. Rev Med Virol. 2018;28:e1977. https://doi.org/10.1002/ rmv.1977.

76. Savarino A, Boelaert JR, Cassone A, Majori G, Cauda R. Effects of chloroquine on viral infections: an old drug against today's diseases? Lancet Infect Dis. 2003;3:722-7. https://doi.org/10. 1016/s1473-3099(03)00806-5.

77. Zhou D, Dai SM, Tong Q. COVID-19: a recommendation to examine the effect of hydroxychloroquine in preventing infection and progression. J Antimicrob Chemother. 2020;75:1667-70. https://doi.org/10.1093/jac/dkaa114 (This study summarized the promising role of hydroxychloroquine in preventing the COVID-19 infection).

78. Devaux CA, Rolain JM, Colson P, Raoult D. New insights on the antiviral effects of chloroquine against coronavirus: what to expect for COVID-19? Int J Antimicrob Agents. 2020;55:105938. https://doi.org/10.1016/j.ijantimicag.2020.105938 (the main highlights of this study is to describe recent advancement in COVID-19 therapeutic approaches using chloroquine).

79.•• Yao X, Ye F, Zhang M, Cui C, Huang B, Niu P, et al. In vitro antiviral activity and projection of optimized dosing design of hydroxychloroquine for the treatment of severe acute respiratory syndrome coronavirus 2 (SARS-CoV-2). Clin Infect Dis. 2020: ciaa 237 . https://doi.org/10.1093/cid/ciaa237 The study highlights the utility of hydroxychloroquine in the treatment of SARS-CoV-2.

80.• Colson P, Rolain JM, Lagier JC, Brouqui P, Raoult D. Chloroquine and hydroxychloroquine as available weapons to fight COVID-19. Int J Antimicrob Agents. 2020;55:105932. https://doi.org/10.1016/j.ijantimicag.2020.105932 Describes the role of Chloroquine and hydroxychloroquine in COVID-19 treatment.

81. National Health Commission and State Administration of Traditional Chinese Medicine. Diagnosis and treatment protocol for novel coronavirus pneumonia. https://www.chinalawtranslate. com/wp-content/uploads/2020/03/Who-translation.pdf. Accessed March 18, 2020.

82. Hydroxychloroquine [database online]. Hudson, OH: Lexicomp Inc; 2016. http://online.lexi.com. Accessed March 17, 2020.

83. Chu CM, Cheng VCC, Hung IFN, Wong MML, Chan KH, Chan $\mathrm{KS}$, et al. Role of lopinavir/ritonavir in the treatment of SARS: initial virological and clinical findings. Thorax. 2004;59:252-6. https://doi.org/10.1136/thorax.2003.012658.
84. de Wilde AH, Jochmans D, Posthuma CC, Zevenhoven-Dobbe JC, Nieuwkoop SV, et al. Screening of an FDA-approved compound library identifies four small-molecule inhibitors of Middle East respiratory syndrome coronavirus replication in cell culture. Antimicrob Agents Chemother. 2014;58:4875-84. https://doi.org/ 10.1128/AAC.03011-14.

85. Dong L, Hu S, Gao J. Discovering drugs to treat coronavirus disease 2019 (COVID-19). Drug Discov Ther. 2020;14:58-60. https://doi.org/10.5582/ddt.2020.01012.

86. Yao TT, Qian JD, Zhu WY, Wang Y, Wang GQ. A systematic review of lopinavir therapy for SARS coronavirus and MERS coronavirus-A possible reference for coronavirus disease-19 treatment option. J Med Virol. 2020;92:556-63. https://doi.org/10. 1002/jmv.25729.

87. Chan KS, Lai ST, Chu CM, Tsui E, Tam CY, Wong MML. et al.Treatment of severe acute respiratory syndrome with lopinavir/ritonavir: a multicentre retrospective matched cohort study. Hong Kong Med J. 2003;9:399-406.

88. Stockman LJ, Bellamy R, Garner P. SARS: systematic review of treatment effects. PLoS Med. 2006;3:e343. https://doi.org/10. 1371/journal.pmed.0030343.

89. Foolad F, Aitken SL, Shigle TL, Prayag A, Ghantoji S, ArizaHeredia E, et al. Oral versus aerosolized ribavirin for the treatment of respiratory syncytial virus infections in hematopoietic cell transplant recipients. Clin Infect Dis. 2019;68:1641-9. https:// doi.org/10.1093/cid/ciy760.

90. Arabi YM, Shalhoub S, Mandourah Y, Al-Hameed F, Al-Omari A, et al. Ribavirin and interferon therapy for critically ill patients with Middle East respiratory syndrome: a multicenter observational study. Clin Infect Dis. 2020;70:1837-44. https://doi.org/10. 1093/cid/ciz544.

91. Siegel D, Hui HC, Doerffler E, O'Clarke M, Chun K, et al. Discovery and Synthesis of a phosphoramidate prodrug of a Pyrrolo[2,1-f][triazin-4-amino] Adenine C-Nucleoside (GS5734) for the treatment of Ebola and emerging viruses. J Med Chem. 2017;60:1648-61. https://doi.org/10.1021/acs.jmedchem. $6 \mathrm{~b} 01594$.

92. Al-Tawfiq JA, Al-Homoud AH, Memish ZA. Remdesivir as a possible therapeutic option for the COVID-19. Travel Med Infect Dis. 2020;34:101615. https://doi.org/10.1016/j.tmaid. 2020.101615 The study highlights role of remdesivir as promising therapeutic drug to combat COVID-19.

93.• Wang M, Cao R, Zhang L, Yang X, Liu J, et al. Remdesivir and chloroquine effectively inhibit the recently emerged novel coronavirus (2019-nCoV) in vitro. Cell Res. 2020;30:269-71. https:// doi.org/10.1038/s41422-020-0282-0 The study summarized the effect of remdesivir and chloroquine in the management of COVID-19.

94.• Sheahan TP, Sims AC, Leist SR, Schäfer A, Won J, et al. Comparative therapeutic efficacy of remdesivir and combination lopinavir, ritonavir, and interferon beta against MERS-CoV. Nat Commun. 2020;11:1-4. https://doi.org/10.1038/s41467-01975313940-6 The study describes comparative therapeutic effect of remdesivir and combination of lopinavir, ritonavir.

95.• Horby P, Lim WS, Emberson JR, Mafham M, Bell JL, Linsell L, et al. Dexamethasone in Hospitalized Patients with Covid-19Preliminary Report. N Engl J Med. 2020; This investigation has explored the utility to reduce the mortality rate in COVID-19 patients by using dexamethasone.

96. Huang I, Lim MA, Pranata R. Diabetes mellitus is associated with increased mortality and severity of disease in COVID-19 pneumonia - a systematic review, meta-analysis, and meta-regression: diabetes and COVID-19. Diabetes Metab Syndr Clin Res Rev. 2020;14:395-403.

97. Pranata R, Lim MA, Huang I, et al. Hypertension is associated with increased mortality and severity of disease in COVID-19 
pneumonia: a systematic review, meta-analysis and meta-regression. J Renin-Angiotensin-Aldosterone Syst. 2020;21: 1470320320926899.

98. Pranata R, Soeroto AY, Huang I, et al. Effect of chronic obstructive pulmonary disease and smoking on the outcome of COVID19. Int J Tuberc Lung Dis. https://doi.org/10.5588/ijtld.20.0278.

99. Pranata R, Huang I, Lim MA, et al. Impact of cerebrovascular and cardiovascular diseases on mortality and severity of COVID-19 systematic review, meta-analysis, and meta-regression. J Stroke Cerebrovasc Dis. https://doi.org/10.1016/j.jstrokecerebrovasdis. 2020.104949.

100. Pranata R, Tondas AE, Huang I, et al. Potential role of telemedicine in solving ST-segment elevation dilemmas in remote areas during the COVID-19 pandemic. Am J Emerg Med. https://doi. org/10.1016/j.ajem.2020.06.012.

101. Huang I, Pranata R. Lymphopenia in severe coronavirus disease2019 (COVID-19): systematic review and meta-analysis. J Intensive Care. 2020;8:36.

102. Theoharides TC, Conti P. Dexamethasone for COVID-19? Not so fast. J Biol Regul Homeost Agents. 34. https://doi.org/10.23812/ 20-EDITORIAL_1-5.

Publisher's Note Springer Nature remains neutral with regard to jurisdictional claims in published maps and institutional affiliations. 